\title{
PLANNING AND REGIONAL SCIENCE
}

\author{
Robert B. Begg*
}

There are two skillful evasions of a meaningful discussion of the relationship between planning and regional science. Working within the framework of regional science, one can look quickly at the long-term and healthy relationship between a handful of regional economics techniques (Richardson 1978) and the planning profession. Although these techniques are important in defining the relationship between planning and regional science, a discussion of them could be brief and rather pedestrian.

A more skillful exit from considering real issues would be to turn to the recent and persistent self-examination of academic planners. Always prone to introspection and self-criticism, academic planners have been confessing recently that what occurs in the halls of academe may be unresponsive and irrelevant to the real life of planners (Levy 1992, 1990; Beauregard 1990; Brooks 1990, 1988; Hall 1989). If the discipline of planning is tangential to the profession of planning, what role can regional science be expected to play?

In spite of the temptation to either restrict these comments to the safe and mundane, or, alternatively, to turn them into a polemic on what is wrong with the world in general, and with regional science and planning as academic disciplines in particular, I will try to walk a middle road.

Rather than tackle the entire relationship between two expansive disciplines, I want to focus on three changes in the profession of planning that have occurred over the past 12 years and to look at the ways in which regional science has and might respond to these changes.

The areas I discuss include: the planner as entrepreneur, the relocation of planning to the urban fringe, and a reemerging concern with the distributional effects of economic development. Even these areas are vast and omit much that is important, but I believe they serve as a basis from which to make some generalizations.

\section{THE PLANNER AS ENTREPRENEUR}

The capitalist entrepreneur is the dominant metaphor for economic development planning in the United States. Frieden (1990) and Sagalyn (1990) have

*Associate Professor of Geography and Regional Planning, Indiana University of Pennsylvania. 
documented the rise of the entrepreneurial planner in America's cities. Sagalyn argues that the decline of federal largesse and an emphasis on public-private partnerships have pushed planners into the arena of development and deal making. The public development of real estate takes many forms. At the extreme, a city engages in feasibility studies, assembles land, obtains financing, and manages property directly or through an intermediary (Frieden 1990). Some cities, including Hartford and Saint Paul, have negotiated partial ownership in local businesses. Planners thrown into the process may lack some of the skills necessary to hold their own in dealing with private interests. Frieden argues that a better knowledge of real estate, finance, negotiation, and politics are important if public sector development is to succeed.

Naive of the process of deal making, planners may greatly underestimate the benefits they are selling (Frieden 1990; McClure 1990). There are also important distributional effects to the process of public sector development that may not be adequately considered (Robinson 1989; Thomas 1990).

Even beyond the special case of public sector development, the planner's vocabulary for the 1990s is one of negotiation, deal making, leveraging, and packaging. McClendon $(1988,1991)$ makes the argument from a different perspective. In Mastering Change, a short-term best seller for Planner's Press, he argues that the survival of planning agencies and planners, if not of communities, hinges on being responsive to client needs. High-quality professional reports that respond to the needs of politicians and the business community are part of the hard sell he advocates. Such reports demand a new breed of planner. From this perspective, the planning office becomes a consulting firm. The growth of GIS as a mainstay of planning departments is indicative of the demand for quickly generating, attractive, and easily interpreted demographic, infrastructure, and economic reports.

Levy $(1990,154)$ tells us that the directors of economic development agencies see the marketing of sites and structures as the "most important and . . . most productive aspect of their work." He speaks of flexibility, adaptiveness, and quickness of response as being the new demands on a successful planner, and he ties this to "a near obsession with economic development" (1992, 81-82). One of the top selling books for ICMA is Black's Achieving Economic Development Success: Tools that Work (1991). ${ }^{1}$ Fainstein tells us that "the motivation for planning [within the United States] . . is economic growth and the strategies for achieving it reflect the exigencies of a highly competitive capitalist economy" (1991, 32).

Within this context-that of the entrepreneurial capitalist planner cutting deals and developing property-is there a role for regional science, and have regional scientists stepped forward to fill it? The answers, as near as I can tell, are "yes" and "sort of." 
One question that planners need answered, which is one we have been asking ourselves for some time, is what works. What strategies of regional entrepreneurial economic development are worth pursuing? What infrastructure needs to be built? What sectors are going to have to stimulate broader development? And, at a more fundamental level, what questions should we be asking?

Regional science has all the skills and tools to answer such questions. And there are a number of "cross-over" scholars who have begun to do so. Markusen (1988) has tried to turn her research on industrial decline into practical advice for economic development planners. Hansen has not only looked at economic development, but has provided advice on strategies that work. Fisher (1988) examines state efforts at managing venture capital.

In general, however, the gap between what we could say and what we do say is great. By perusing some of the regional science joumals of the last few years, one finds a number of relevant articles that could be tumed into the kinds of advice economic development planners need. These articles cover such subjects as the role of services in generating economic growth, analysis of industrial parks, the role of small businesses on growth in various regional environments, the role of high-tech industry in economic growth, data requirements for strategic planning in an urban neighborhood, export markets and regional growth, and a number on the impact of taxes and incentives. Although some of these articles are accessible, far too many are in the jargon of regional economics. Autoregressive models mean little to the planner for whom press releases outweigh location quotients in importance (Levy 1990).

This is not a criticism of regional science. I am not arguing that the Journal of Regional Science should ignore important work in theoretical regional economics or discourage good technique in applied articles. There is, however, a serious mismatch between what we do and what planners are able to use. As recently as 1988 (Contant and Forkenbrock 1988), fewer than one-quarter of planning schools required econometric modelling, and more than half the planning agencies had no one who could understand it. Nonlinear programming fared worse, and network modelling fared almost as badly. Some of our techniques (economic base, shift-share, input-output) are taught in more than half of the planning programs and have someone on staff in more than half the agencies who understands them. But fewer than one-third of the planning agencies see these techniques as important.

There is a role, then, for interpreters-people who can pull together work on regional economic development, generalize it in a useful way, and make it accessible to economic development planners. In reviewing the plethora of how-to books on the market, one finds them too general, often out-of-date, anecdotal, and laced with Pollyannaisms that are a disservice to economic development planners. 
If we have been remiss in making the work we do accessible, the gap between what we could know and what we do know is even greater.

In 1978, Richardson suggested that new areas of policy study were opening up for regional economists. Among them he noted: "The importance of amenities as a locational attractor, the implications for spatial distributions of interregional shifts of industry, the decline of large cities ... explaining the relocation of firms" $(1978,34)$. Although some of the problems fall within the boundaries of regional economics, "economists cannot find the answers alone ... it is probable the disciplinary shackles of the economists constrain his capacity to solve these problems ... only the new discipline of regional science offers him freedom from the stifling influence of the great but limited neoclassical tradition" $(1978,34)$.

I think some of us might be tempted to make the same statement today. If we have not made sufficient progress, I think it is because there are two problems we need to deal with. The first is to clearly update texts on regional economic development theory. The second is to make available expanded and simplified forms of policy analysis.

Niles Hansen (1988) takes regional science to task for its failure to explain the regional consequences of the new international division of labor. Old ideas of comparative advantage, urban hierarchies, and agglomeration economies do not explain the patterns of regional growth during the 1980s. Indeed, a number of our generalizations-Frost Belt/Sun Belt, deindustrialization, counterurbanization-do not bear up under close scrutiny. He suggests that models such as the product cycle and process cycle offer a better chance of understanding regional industrial development in the post-Ford era. Markusen (1985) has offered the "profit cycle" as another alternative. Schoenberger (1988) goes further yet. She suggests that the concept of the new international division of labor, based in part on the productcycle model, is itself an oversimplification of regional development. Her basic argument is that we tend to view the location process from the cost minimization perspective, and that this is a great oversimplification of the production location decision. Factors of supply and market have been shown to have a much greater effect in certain sectors. Even sectors as labor intensive as textiles can make counterintuitive location decisions for reason of product mix or market. Ettlinger (1992) argued that the notion of comparative advantage is insufficient and instead offered a concept of competitive advantage that includes an institutional, spatial, and regulatory framework. Her argument draws on the long-term development of Japan and California.

This is not a review of regional growth theory. The point is that we are beginning to restructure much of what was once dogma in the face of changing global and national economies. Some notions are not foreign, but will receive new emphasis. In attempting to understand regional growth, markets have a heightened 
prominence. Variations in occupational structure may add to our understanding in ways that the analysis of the more traditional variation in sectoral structure does not. Institutional and regulatory context can have a profound effect, especially in the long run. Understanding industrial change today has become a sector-specific and firm-type specific undertaking. Understanding clearly industrial process may be a necessary tool for future development planners. Cheap labor, inexpensive land, and tax breaks are probably not the tools of choice within this new framework. Blakely's (1989) popular economic development text incorporated some of these new understandings. The "third Italy" sneaks in at the end of his text. Much remains to be done, however, before this package becomes coherent. And somebody has to turn it into a package that planners can understand and use.

In spite of Richardson's call to arms 14 years ago, good policy analysis and relevant case study are still too small a part of the regional science literature on economic development. In this light, Isserman and Beaumont's work on quasi-experimental modelling may be a step in the right direction. A tool like the quasi-experimental model, if made available, could greatly extend the abilities of planners to ask and answer relevant questions. Input-output packages are becoming accessible to local planners, providing the promise of more accurate and detailed impact analysis. The relatively new Economic Development Quarterly is a promising signal that careful science can have a forum. What regional scientists need to do, if they wish to be heard by planners, is to adopt tools and use language and platforms that are accessible to planners.

\section{MOVE TO THE SUBURBS}

Perhaps the dominant theme for planners in the late 1980s was the emergence of what Garreau (1991) has christened the "Edge City." Today 62 percent of all workers are intrasuburban commuters, and for almost 10 years, there have been more jobs in the suburbs of northeastern cities than in the cities themselves (Chinitz 1990). Hall $(1989,281)$ identifies the new problems of the eighties as "the growth of the suburbs, the development within them of entirely new service nodes, ... the rapid spread of suburban gridlock as infrastructure of the sixties is overwhelmed, the problems of water supply, waste management, the loss of urban space and rural qualities of huge swathes of land around metropolitan areas, and ... the arrival of NIMBYism as the populist philosophy of the 1980's."

These problems of growth and spread, which dominate the lives of most Americans, are ones that planners as of yet have no clear and consistent set of answers for, Hall argues. However, they have been preoccupied with the development of tools and programs for this purpose. Among the most frequent articles in 
planning joumals and among the greatest variety of books are those on various forms of growth controls. Performance zoning, growth control ordinances, development impact fees, TDRs, and user assessments are part of the new vocabulary of the suburban planner, as much as the language of speculative capitalism has become second nature to the economic development planner. Local initiatives abound, and Oregon, Florida, Maine, Vermont, Rhode Island, and New Jersey have made efforts to deal with the problem at the state level. Florida's 1985 growth control legislation has received a great deal of attention.

One might guess that suburban growth and the legislative control of that growth would be less likely to attract the attention of regional science. It engenders, however, the discussion of issues in which regional scientists have stepped forward. On issues of economic development, one looks in vain for crossreference from JAPA to regional science journals. On the issue of growth control, cross-references, if scarce, at least exist. Chinitz $(1989,1990)$ has entered the fray with a general discussion of growth control legislation and environmental quality. The entire issue of whether forcing concentrated development is or is not an efficient use of resources has generated discussion regarding housing markets and residential preference (Auridoc, Shermyen, and Smith 1990), transportation and energy efficiency (Gordon, Richardson, and Jun 1989), the relationship between land use and transportation (Hanson 1992), and office and retail location (Pivo 1990). Here regional scientists have directly entered the argument or are referred to with some regularity.

Perhaps when it comes to questions of regional land use, location, and transportation, regional scientists are on firmer ground. To some extent, these are issues of efficient allocation or simultaneous equilibrium. We have Lowry-type and entropy models, travel demand and programming techniques, and location algorithms at our disposal. We have just been waiting for someone to ask. While not in favor of sprawl, we can in general clearly assess its costs and benefits within a coherent framework. Gordon and Richardson (1989), for example, argue that the light-rail schemes and stricter land use controls proposed by Newman and Kenworthy (1989) entirely miss the point in regard to their ability to save energy, increase efficiency, and direct development. Contributions such as this, which are well grounded on theory and empirical research, are the kind that regional scientists ought to be making. If we were as clear in our pronouncements on economic development, planners might avoid much fleece chasing.

We have had less to say about the ultimate social costs of growth controls. This area may well demand increasing attention in the 1990s. 


\section{DISTRIBUTION}

Although it is hard to imagine that, as Dennis Hopper has said, the nineties will make the sixties look like the fifties, Peter Hall (1989) may be more accurate when he compares the urban ills of the 1990s to those of the 1890s: a period that, in many ways, gave birth to urban planning. Calling the entire history of planning "The City Pathological Revisited," Hall reminds us that, as business and the white majority have abandoned the inner city, its ills have gone unremedied. His call is not alone.

The whole subject of urban inequity is being revisited and seen more accurately as complex and deep-seated. Nathan Glazer (1989) cautions us that in calling for a "kinder and gentler America," we must realize the solutions will not be simple, and he warns that knowledge and honesty must be two of the tools. Similarly, Herbert Gans (1990) calls for a deconstructing of the "underclass." In reviewing the persistence and complexity of the problem, he fears the term may be a tool in accepting a permanent division in society.

One salient issue in the debate is what Hall has called "the Rousification of the downtown." Festival market places and downtown developments may be displacing the poor and providing only limited benefit for everyone (Giloth and Betancur 1988; Rubenstein 1988). The entrepreneurial and public development initiatives that planners have suggested in the early 1990s may not ameliorate the persistent and visceral ills of the downtown.

In reviewing downtown plans for the 1980s, Keating and Krumholz (1991) call for a greater equity in the plans of the 1990s. Three specific suggestions stem from their analysis. They ask for a clear assessment of the social costs and benefits of downtown plans, developer "linkage requirements," and "first source" hiring policies. Linkage is one of the strategies that appears to be gaining in popularity. Keating (1986) is pessimistic about the experiences of three cities (Boston, San Francisco, and Santa Monica) in using downtown linkages to ameliorate social problems. He suggests that incentive zoning and downtown assessment districts can do a better job. Nelson (1988) identifies these as linkage by another name and argues that they simply steer office development to the suburbs. Huffman and Smith (1988) provide empirical evidence from Philadelphia to support this contention.

In a broader survey of urban economic development policies, Robinson (1989) finds that those cities that see themselves as actively guiding development are far more likely to urge issues of social infrastructure development and to consider location as a tool to redress job opportunity inequities. Her analysis suggests that the more active role the city takes in "public development," the more likely it 
is to be able to address social issues. Thomas (1990) makes similar arguments about Detroit.

The distributional impacts of policy or investment are precisely the kind of issues where regional science can offer advice. Tools such as input-output can trace the distributional effects of employment and investment (Rose and Beaumont 1988; Batty and Madden 1983). Housing market analysis and location decisions in the context of downtown development incentives or fees are fair game for modelling. The task here is not to solve the problems of cities, but rather, more modestly, to calculate the distributional consequences of varying development strategies.

\section{CONCLUSION}

These are not the only areas in which regional science and planning meet. Regional science techniques still figure prominently in the methods of planning (e.g., ReVelle 1991). International comparisons are a sphere where regional science has much to contribute (e.g., Alonso 1991). But the areas discussed here reveal a central theme. In the focal areas of entrepreneurial economic development, suburban growth, and metropolitan poverty, regional scientists have said less than they could to planners and have grappled insufficiently with broad but clear policy issues.

For example, although Frieden refers to some 50 to 100 state and local governments involved in public sector development, much of what economic developers do (Levy 1990) looks a lot like smokestack chasing. Thomas (1990), in studying Detroit, argues that the more common tools of today's economic development planner-those of recruitment incentives-would have been great in the postwar period but are out of step now. If some big city planners have seen the handwriting on the wall, many county and small town planners have not.

Vacant industrial parks are still being built. Empty festival market places and boarded up theme parks still exist outside of Flint, Michigan. State and local governments offer $\$ 30$ billion in incentives to business a year, some 20,000 state and local agencies compete for roughly 700 annual industrial locations (Black 1991). The nature and futility of this zero-sum game, or worse, is not news to us. I have yet to find a clear and convincing statement that has made this point to planners.

Distributional impacts of metropolitan policy ought to be meat and potatoes to regional scientists, but how much have we analyzed, how much have we said, and in what way have we said it? 
Finally, many, if not most, of the issues that planners cope with concem regional growth, efficient resource allocation over space, and today, the distributional or environmental impacts of policy at the regional scale.

In recapping the history of planning, Hall (1989) speaks fondly of the vision of Lewis Mumford, Clarence Stein, Stuart Chase, Benton MacKaye, and Catherine Bauer when they formed the Regional Planning Association of America. He laments the demise of their vision to Rousified newtowns and downtowns. He calls for new Mumfords, Tugwells, and Perloffs. But that is our heritage, too. In a wonderfully obscure treasure of mine (vol. 1, no. 1 of the Indian Journal of Regional Science), Walter Isard (Isard and Chatterji 1968, 22) says unequivocally: "Regional Science provides the theoretically and scientifically operational basis for Regional Planning." I would argue that we need to provide it more clearly, more relevantly, and with more vision.

\section{ENDNOTES}

1. Barbara Moore, ICMA. Phone conversation of March 30, 1992. The top five sellers include The Practice of Local Government Planning (the green bible), Balanced Growth, Taking Charge, and various books on GIS, developer financing, and development impact fees.

\section{REFERENCES}

Alonso, William. "Europe's Urban System and its Peripheries." Journal of the American Planning Association 57, no. 1 (1991): 6-12.

Andrew, Christine, and Dwight Merriam. "Defensible Linkage." Journal of the American Planning Association 54, no. 2 (1988): 199-209.

Auridoc, Ivonne, Anne Sherymen, and Mark Smith. "Ideal Urban Form and Visions of the Good Life: Florida's Growth Management Dilemma." Journal of the American Planning Association 56, no. 4 (1990): 470-82.

Battey, Peter, and M. Madden. "The Modeling of Demographic-Economic

Change Within the Context of Regional Decline." Socio-Economic Planning Sciences 17 (1983): 315-28.

Beauregard, Robert A. "Bringing the City Back In." Journal of the American Planning Association 56, no. 2 (1990): 210-14.

Black, Henry. Achieving Economic Development Success: Tools that Work. ICMA, 1991. 
Blakely, Edward J. Planning Local Economic Development. Sage Publications, 1989.

Brooks, Michael P. "The City May Be Back In, but Where is the Planner?" Journal of the American Planning Association 56, no. 2 (1990): 218-21.

"Four Critical Junctures in the History of the Urban Planning Profession." Journal of the American Planning Association 54, 2 (1988): 241-48.

Chinitz, Benjamin. "Growth Management from an Economist's Perspective." Journal of the American Planning Association 55, no. 3 (1989): 338-39.

"Growth Management: Good for the Town, Bad for the Nation?" Journal of the American Planning Association 56, no. 1 (1990): 3-8.

Contant, Cheryl K., and David Forkenbrock. "Planning Methods: An Analysis of Supply and Demand." Journal of Planning Education and Research 6, no. 2 (1986): 10-21.

DeGrove, John M., ed. Balanced Growth: A Planning Guide for Local Government. IMCA, 1991.

Eisner, Robert. "Our Real Defects." Journal of the American Planning Association 57, 2 (1991): 131-35.

Ettlinger, Nancy. "The Roots of Competitive Advantage in California and Japan." Annals of the Association of American Geographers 81, no. 3 (1991): 391-407.

Fainstein, Susan S. "Promoting Economic Development." Journal of the American Planning Association 57, no. 1 (1991): 22-33.

Fisher, Peter. "State Venture Capital Funds as an Economic Development Strategy." Journal of the American Planning Association 54, no. 2 (1988): 166-77.

Frieden, Bernard J. "Planners as Developers." Journal of the American Planning Association 56, no. 4 (1990): 423-28.

Garreau, Joel. Edge City. New York: Doubleday, 1991.

Gans, Herbert. "Deconstructing the Underclass: The Term's Dangers as a Planning Concept." Journal of the American Planning Association 56, no. 3 (1990): 271-77.

Giloth, Robert, and John Betancur. "Where Downtown Meets Neighborhood: Industrial Displacement in Chicago, 1978-1987." Journal of the American Planning Association 54, no. 3 (1988): 279-90.

Glazer, Nathan. "A Kinder and Gentler America, I: Moving from Slogan to Reality." Journal of the American Planning Association 55, no. 4 (1989): 411-15. 
Gorden, Peter, and Harry W. Richardson. "Gasoline Consumption and Cities: A Reply." Journal of the American Planning Association 55, no. 3 (1989): 342-46.

Gordon, Peter, Harry W. Richardson, and M. Jun. "The Communicating Paradox: Evidence from the Top Twenty." Journal of the American Planning Association 57, no. 4 (1991): 416-20.

Hall, Peter. "The Turbulent Eighth Decade: Challenges to American City Planning." Journal of the American Planning Association 55, no. 3 (1989): 275-82.

Hansen, Niles. "Regional Consequences of Structural Changes in the National and International Division of Labor." International Regional Science Review 11, no. 2 (1988): 121-36.

Hanson, Mark. "Automobile Subsidies and Land Use: Estimates and Policy Responses." Journal of the American Planning Association 58, no. 1 (1992): 60-71.

Harvey, David. "On Planning the Ideology of Planning." In Planning Theory in the 1980's, edited by Robert W. Burchell and George Sternlieb, 213-234. New Brunswick: Center for Urban Policy Research, 1978.

- Huffman, Forrest E., and Marc T. Smith. "Market Effects of Office Development Linkage Fees." Journal of the American Planning Association 54, no. 2 (1988): 217-24.

Isard, Walter, and M. Chaterjee. "Potentialities of Regional Methods and Techniques in Attacking Indian Regional Science Problems." Indian Journal of Regional Science 1, no. 1 (1968): 1-23.

Jones, Bernie. Neighborhood Planning. APA Planners Press, 1990.

Keating, W. Dennis. "Linking Downtown Development to Broader Community Goals: An Analysis of Linkage Policy in Three Cities." Journal of the American Planning Association 52, no. 2 (1986): 133-41.

Keating, W. Dennis, and Norman Krunholz. "Downtown Plans of the 1980s: The Case of More Equity in the 1990s." Journal of the American Planning Association 57, no. 2 (1991): 136-52.

Klein, Richard D. Everyone Wins! A Citizen's Guide to Development. APA Planners Press, 1990.

Levy, John M. "What Has Happened to Planning?" Journal of the American Planning Association 58, no. 1 (1992): 81-84.

"What Local Economic Developers Actually Do: Location Quotients versus Press Releases." Journal of the American Planning Association 56, no. 2 (1990): 153-60. 
Markusen, Ann R. "Planning for Industrial Decline: Lessons from the Steel Communities." Journal of Planning Education and Research 7, no. 3 (1988): 173-84.

Profit Cycles, Oligopoly, and Regional Development. Cambridge: MIT Press, 1985.

Markusen, Ann, Helzi Noponen, and Karl Driessen. "International Trade, Productivity, and U.S. Regional Job Growth: A Shift-Share Interpretation." International Regional Science Review 14, no. 1 (1991): 15-40.

McClendon, Bruce W. "Customer Service: A New Philosophy Towards Effective City Planning." Journal of the American Planning Association 57, no. 2 (1991): 205-211.

McClendon, Bruce W., and Ray Quay. Mastering Change: Winning Strategies for Effective City Planning. APA Planners Press, 1988.

McClure, Kirk. "Low and Moderate Income Housing Credits: Calculating Their Value." Journal of the American Planning Association 56, no. 3 (1990): 363-69.

Nelson, Arthur. "Symposium: Linkage Fee Programs. Introduction: Downtown Office Development and Housing Linkage Fees." Journal of the American Planning Association 54, no. 2 (1988): 197-98.

Newman, Peter W. G., and Jeffrey R. Kenworthy. "Gasoline Consumption and Cities: A Comparison of U.S. Cities with a Global Survey." Journal of the American Planning Association 55, no. 1 (1988): 24-37.

Pivo, Gary. "The Net of Mixed Beads: Suburban Office Development in Six Metropolitan Regions." Journal of the American Planning Association 56, no. 4 (1990): 457-69.

Robinson, Carla J. "Municipal Approaches to Economic Development: Growth and Distribution Policy." Journal of the American Planning Association 55, no. 3 (1989): 283-96.

ReVelle, Charles. "Siting Ambulances and Fire Companies: New Tools for Planners." Journal of the American Planning Association 57, no. 4 (1991): 471-84.

Rose, Adam, and Paul Beaumont. "Interrelational Income Distribution Multipliers for the West Virginia Economy." Journal of Regional Science 28, no. 4 (1988): 461-76.

Richardson, Harry W. "The State of Regional Economics: A Survey Article." International Regional Science Review 3, no. 1 (1978): 1-48.

Rubenstein, James. "Relocation of Families for Public Improvement Projects: Lessons from Baltimore." Journal of the American Planning Association 54, no. 2 (1988): 185-96. 
Sagalyn, Lynne B. "Explaining the Improbable: Local Redevelopment in the Wake of Federal Cutbacks." Journal of the American Planning Association 56, no. 4 (1990): 429-41.

San Jose, Julio. "A Kinder and Gentler America, II: A Visual Essay." Journal of the American Planning Association 55, no. 4 (1989): 416-17.

Schoenberger, Erica. "Multinational Corporations and the New International Division of Labor." International Regional Science Review 11, no. 2 (1988): 105-21.

So, Frank S., and Judith Getzels, eds. The Practice of Local Government Planning. ICMA and APA Planners Press, 1988.

Solnit, Albert. The Job of the Planning Commissioner. APA Planners Press, 1987. The Job of the Practicing Planner. APA Planners Press, 1988.

Thomas, June M. "Planning and Industrial Decline: Lessons from Postwar Detroit." Journal of the American Planning Association 56, no. 3 (1990): 297-310. 